\title{
Colonial adventures in tropical agriculture: new estimates of returns to investment in the Netherlands Indies, 1919-1938
}

\author{
Frans Buelens ${ }^{1} \cdot$ Ewout Frankema ${ }^{2}$
}

Received: 16 January 2015/ Accepted: 1 April 2015/Published online: 15 May 2015

(C) The Author(s) 2015. This article is published with open access at Springerlink.com

\begin{abstract}
How profitable were foreign investments in plantation agriculture in the Netherlands Indies during the late colonial era? We use a new dataset of monthly quoted stock prices and dividends of international companies at the Brussels stock exchange to estimate the returns to investment in tropical agriculture (1919-1938). We adopt the Dimson-March-Staunton method to compute real geometric annual average rates of return and assess our estimates in an international comparative perspective. We find that returns to colonial FDI in the Netherlands Indies during 1919-1928 were impressive (14.3\%), being almost 3 percentage points higher than the world average. In the following decade 1929-1938 fortunes reversed, with a rate of return of $-2.8 \%$ compared to a world average of $2.2 \%$. Over the entire period the returns to colonial FDI (5.4\% in 1919-1938) were about a factor 2.5 higher than returns to investment in the Dutch domestic economy (2.1\% in 1920-1939). We argue that these returns should be interpreted in a colonial context of systematic labour repression, but that they may also partly reflect a higher risk-premium of investments in colonial commodities.
\end{abstract}

Keywords FDI · Netherlands Indies - Colonial economy · Tropical agriculture · Returns to investment

JEL Classification N25 $\cdot$ N45 $\cdot$ N55

Ewout Frankema

ewout.frankema@wur.nl

1 University of Antwerp, Antwerp, Belgium

2 Wageningen University, Wageningen, The Netherlands 


\section{Introduction}

In the mid-19th century, when the Portuguese and Spanish empires were crumbling and the heydays of French, German, Belgian and Japanese imperial expansion were yet to come, the Netherlands were regarded as the second most important imperial power after Britain. In a book published in 1861 "Java, or how to manage a colony showing a practical solution of the questions now affecting British India" J.B.W. Money suggested the Netherlands Indies as a model colony for British India (Wesseling 1988, 140-176). The effectiveness of Dutch extractive policies in the Indonesian archipelago also formed a source of inspiration for the Belgian King Leopold II, who aspired to turn Belgium into a colonial power, and eventually acquired a vast territory in the Congo basin under private royal control (Stengers 1977; Vanthemsche 2007).

The extraordinary profitability of the 'cultivation system' introduced by the Dutch on Java in the 1830s, contributed substantially to the economic development of the metropole. At its peak, in the 1850s, the forced cultivation of sugar, tea, indigo and coffee by Javanese peasants contributed an estimated $52 \%$ to Dutch central tax revenues and an estimated $4 \%$ to Dutch GDP (van Zanden and van Riel 2000, 223). The net surplus on the Indonesian balance of payments was used to service high levels of Dutch state debt, to finance Dutch infrastructural investments and to subsidize the less 'productive' Dutch colonies in the West Indies (Geertz 1963; Elson 1994; Booth 1998; Lindblad 1989; van Zanden 2004).

The historical debate on the late colonial era, with which we engage in this study, has been deeply affected by the idea that after the gradual abolition of the cultivation systems after the 1860s, the Dutch kept reaping exceptional returns on colonial investments, although most of it now hinged on private capital investments instead of state-directed programs of forced cultivation (Gerretson 1938; Vandenbosch 1938; Boeke 1940a, b; Derksen and Tinbergen 1980 [1945]; Haccoû 1961; Maddison 1989; Gordon 2010). This view has been scrutinized by a revisionist literature that has criticized the data and estimates that have been used to assess various aspects of colonial FDI in the late colonial era (Baudet and Wijers 1976), as well as attempts to place the discussion on the 'colonial drain' in the wider context of mutual economic interdependence (van der Eng 1998a, b).

The data and methods that have been used to estimate rates of return to investments during the interwar era all suffer substantial flaws. In this paper we address these flaws and offer new estimates of the return to colonial FDI of 17 companies listed at the Brussels stock exchange (BSE) for 1919-1938. We focus our analysis on the interwar decades, but we also present additional estimates for the period 1940-1958. Although our sample is limited by size and type of investment, which makes it impossible to tell exactly how representative they are for the broad range of investments in Indonesian plantation agriculture, we consider this study as a first step in a new research avenue with potentially high returns, especially if historical Dutch stock market data would become available in a future digitization project (as is currently undertaken for French stock markets).

More specifically, the intended contribution of this paper is threefold. Firstly, we introduce a new database with monthly data on dividend yields and capital gains 
from a sample of stock-based companies active in the Netherlands Indies listed at the Brussels stock exchange. These data have been used to estimate returns to FDI in the Belgian Congo (Buelens and Marysse 2009) and can offer a fresh perspective on the study of returns to FDI in the Netherlands Indies. Secondly, we apply the Dimson-March-Staunton (DMS) method to compute rates of return on investment, which is a method that has not been applied before to this case, but adheres much better to generally accepted principles in finance than the methods used in previous studies (Dimson et al. 2002; Brocquet et al. 1997). Thirdly, we are the first to discuss the estimates for the Netherlands Indies in a global comparative perspective, using estimates of returns to FDI in other countries during the interwar era which have all been computed using the DMS-method.

We find that returns to FDI in the Netherlands Indies during 1919-1928 were impressive $(14.3 \%)$, almost 3 percentage points higher than the world average. During 1929-1938 the tides turned, with an average annual rate of return of $-2.8 \%$ compared to a world average of $2.2 \%$. Compared to the general rate of return on the Amsterdam stock exchange, the returns to colonial FDI were considerably higher: $2.1 \%$ for the period $1920-1939$ versus $5.4 \%$ for our sample 1919-1938. However, returns to FDI in the Netherlands Indies were subject to a higher degree of volatility and became worthless after 1940. We will argue that high returns to colonial FDI in tropical agriculture were underpinned by repressive colonial labour policies and cheap access to land, but also may have partly reflected a higher risk-premium.

Section 2 proceeds to discuss Dutch historical perspectives on the profitability of empire. Section 3 discusses patterns of economic specialization and private investment in the Netherlands Indies during the late colonial era. Section 4 discusses existing estimates of returns to investment and Sect. 5 introduces our data and methodology. Section 6 focusses on stock price indices to identify trends in each of the sub-periods. In Sect. 7 we present and discuss our main results. Section 8 places the results in an international perspective and Sect. 9 concludes.

\section{Dutch perspectives on the 'profitability of empire'}

National historiographical assessments of the contribution of 'empire' to the metropolitan economy are remarkably dissimilar (Frankema and Buelens 2013, 3). For Britain there seems to be a consensus that the average British tax payer did not benefit an awful lot from 'empire' (Gann and Duignan 1967; Davis and Huttenback 1986; O'Brien 1988; Offer 1993). For France the debate has recently flared up again, but seems to lean towards the view that empire was a burden, rather than a boon (Huillery 2014; Lefeuvre 2006; Dormois and Crouzet 1998; Marseille 1984). Yet, studies on the 'smaller' colonial powers such as the Netherlands, Belgium and Portugal almost unanimously agree that their empires in Asia, Africa and South America have greatly enriched the metropolitan economy and have impoverished the colonial economy, if not in absolute terms, than certainly from a long-term comparative development perspective (see for Belgium and the Netherlands: Booth 1998, 2007; Stengers 1989; Vanthemsche 2007; Frankema and Buelens 2013). A recent assessment of the contribution of empire to Portuguese economic growth in 
the early-modern era reaches a clear conclusion: "eliminating the economic links to empire would have reduced Portugal's per capita income by at least a fifth"(Costa et al. 2015: 1). Based on an analysis of balance of payment figures Lains (1998) comes to a similar conclusion for Portuguese Africa in the years 1885-1975.

Dutch economists from the left to the right side of the political spectrum all agreed in the 1930s to 1950s that the loss of Indonesia would cause a severe blow to the Dutch economy (Baudet 1980 [1975], 243-248). Surely, these concerns were also fed by sentiments of national pride and prestige. Gerretson $(1938,10)$ remarked that without the East Indies, the Netherlands would fall to the status of a country like Denmark, becoming " a milk farm at the North Sea". Similar sentiments of grandeur played a role in King Leopold's ambition to turn Belgium into a colonial power (Stengers 1977). The widespread perception that the Congo, Indonesia and Portuguese African colonies of Mozambique and Angola were indispensable to the vitality of the metropolitan economy go a long way in explaining why the 'smaller' countries undertook more desperate attempts to 'protect' metropolitan economic interests in times of decolonization. The independence wars in Portuguese Africa in the 1970 s speak to themselves. The Belgians openly supported the secession of Katanga in the 1960s to safeguard their stakes in the copper industry (Brion and Moreau 2006, 310-318). And after 4 years of bloodshed (1945-1949) and the forced recognition of Indonesian independence in 1949, Dutch diplomats did everything to safeguard Dutch company assets, although they eventually could not prevent the nationalization scheme pursued by the Sukarno regime from December 1957 to $1960 .^{1}$

Dutch memories to the high returns of the cultivation system during the mid-19th century, in combination with the business profits generated during the 1920s, fuelled the idea that Indonesia was vital to the development of the metropolitan economy. ${ }^{2}$ Vandenbosch summarized this perception in 1938, stating that "During long periods of Dutch history golden streams of profit did flow from the East Indies to the Netherlands" (1938, 329). Crena de Iongh $(1938,111)$ estimated that $68 \%$ of all returns on Dutch overseas investment came from the Dutch empire. The idea of 'golden streams' were further underpinned by widely quoted statistical estimates of Derksen and Tinbergen (1980 [1945], 225-240), suggesting that the Netherlands Indies contributed an impressive $13.7 \%$ to Dutch national income in the year 1938. Due to Tinbergen's prestige as a Nobel-laureate this figure was accepted as a 'stylised fact' of the colonial relationship by Dutch policy-makers, despite revisions of their estimates for the post-war period. ${ }^{3}$

Gonggrijp (1931) discussed the division of labour between the metropole and the colony arguing that the Dutch managed to develop all kinds of industries, such as

\footnotetext{
${ }^{1}$ In this period virtually all Dutch assets were nationalized with the exception of Shell and Unilever as they were of mixed Anglo-Dutch ownership (Sluyterman 2004, 5).

${ }^{2}$ The profits of the cultivation system inspired the title of a publication by Sandberg (1914) "Indië verloren, rampspoed geboren" (the loss of the East Indies will give birth to disaster). This expression is still in vogue. See Glissenaar (2003).

${ }^{3}$ See for an example of repeated reference to Tinbergen and Derksen's study Nobel and Fennema (1996, 15). See for a critical discussion of Derksen and Tinbergen the work of Gorter (1964) or Baudet and Wijers (1976).
} 
the oil industry, thanks to their colonial possessions. The contribution of the Netherlands Indies to the Dutch dollar surplus during the interwar years, thanks to the large Indonesian rubber exports to the US, was also considered to be of great importance (Booth 1996, 402; Baudet 1980 [1975], 243-244). ${ }^{4}$ Julius Boeke (1940a, b) characterised Dutch colonial policies in terms of a 'drain' that systematically depleted Indonesian resources and impoverished the indigenous population. According to Maddison (1990, 367; see also Maddison 1989) this drain became manifest in a vast export surplus of $12.4 \%$ of GDP in the period 1913-1938, which was much higher than in any other Asian country.

Even though all these figures may have captured part of a historical economic reality, the forecasts all proved wrong. The Dutch economy did not suffer nearly as much as contemporary observers had expected, neither after 1949, nor after 1957 (Baudet and Fennema 1983). By the late 1940s, the Dutch economy stood at the verge of entering a 'golden age' of economic growth, during which the loss of colonial assets after 1957 was easily overcome.

This puzzle has continued to invite debate on the magnitude of the colonial drain and its wider implications (Kuitenbrouwer 1991). van der Eng (1998a, b) discussed the Hobson-Lenin thesis of colonial exploitation arguing that, in a broader comparative perspective, the returns to Dutch FDI in Indonesia were not terribly high compared to the returns on investment in Dutch domestic sectors or compared to other foreign investments. According to van der Eng, the evidence for excessive rent extraction in the late colonial era is weak. Alec Gordon (2010) has argued that previous studies were all wrong to focus exclusively on trade data, and proposed the use of much more detailed balance of payments data to estimate the colonial surplus, which he found to be large by all standards, some 24 billion guilders over the entire period of 1878-1939, equivalent to ca. 156 billion US \$ in 2010 constant values (Gordon 2010, 425 and 440).

\section{Colonial FDI: policies and practices}

Colonial FDI may be regarded as a special type of FDI because the degree of colonial control over institutional arrangements and factor markets may raise the profit potential of foreign investment. One of the motives for metropolitan investors to build up positions in the colonial economy was the implicit assumption that they could obtain higher rates of returns than elsewhere. This, in turn, would also explain part of the economic and political rationale of colonization: why would one bear the costs of controlling overseas territories if it would not enhance opportunities of rent creation and rent extraction? Although some scholars have argued that colonization made little difference for the profitability of investment (Fieldhouse 1961;

\footnotetext{
4 The Dutch also strongly felt that their colonial rule was exceptional: "Contemporary Dutch reaction to other nations' imperialism was often one of disgust and moral condemnation. What the French did in Indochina, let alone the British in South Africa, was something fundamentally different from the reluctant assumption by the Dutch of their responsibilities towards the indigenous peoples of the Indonesian archipelago." (Lindblad 1989, 2). The Belgians thought the same about their rule in the Congo (Etambala 2008).
} 
Wesseling 1988, 94), this position seems hard to sustain for the case of the Netherlands Indies.

During the late 19th and early 20th centuries the general disappointment of Dutch investors with the domestic economy, which was a late and weak industrializing economy by Western European standards, stimulated the search for higher returns all over the world. Dutch investors went heavily into American railways and the mining and plantation sectors of the Netherlands Indies. These investments were made possible by the Agrarian Law of 1870, which marked an important turningpoint in colonial policies regarding foreign private investment (Allen and Donnithorne 1962 [1954], 68). The law stipulated that all virgin and communally tended land belonged to the state and could be privately leased for a period of 75 years (Weijers 1941, 289, Lindblad 1998). In the following decades tropical agricultural commodities such as coffee, tea, sugar, tobacco and, later, palm oil and rubber, became the nexus of both domestic and foreign investment (Forbin 1943). In 1938, the Netherlands Indies supplied about one-third of the world market of rubber, and about one quarter of the world market in palm oil (Boeke 1940a, b I, 188). However, until the 1930s no serious efforts were undertaken to develop the industrial sector (Gordon 1998; Lindblad 2013), while the export sector was increasingly controlled by trusts instead of individual companies since the turn of the century (Allen and Donnithorne 1962 [1954], 31). ${ }^{5}$

Rising demand from industrializing countries in the North Atlantic, together with the rapid decline in ocean freight rates deepened Indonesia's export specialization. The emerging motor car industry created a vast demand for Indonesian rubber and oil. Together with Malaysia (Andaya and Andaya 1982), the Netherlands Indies acquired the main share of world exports of rubber in the 1920s, taking over the early market leaders Brazil and the Belgian Congo, who had relied largely on wild rubber collection (Forbin 1943, 56-69 and 93-106; Purwanto 1996). The dramatic shift in the global location of rubber production corresponded with the rise of plantation-based systems in Southeast Asia, where rubber-trees were planted by large European and Chinese estate-owners as well as by indigenous smallholders taking advantage of highly suitable soils, a substantial labour reservoir, and large reservoirs of Dutch and foreign capital looking for profitable overseas investments.

The total stock of FDI has been estimated at 750 million guilders in 1900, 1, 5 billion in 1914 and 4 billion guilders in 1930 (Lindblad 1991, 183-208; Callis 1942, 28-41). Weijers $(1941,306)$ has estimated that by 1940, Dutch colonial investments amounted to 5 billion guilders, which constituted ca. $20 \%$ of the total Dutch capital stock, one of the highest percentages in the world. According to Weijers, 2 billion guilders were invested in tropical agriculture, with ca. 700 million guilders in the rubber sector and another 150 million in the palm oil sector (1941, 301 and 317-18). American, British, French and Belgian companies also made considerable investments, up to 1 billion guilders according to Gonggrijp (1957, 167). The Netherlands Indies were also important for the Japanese war effort in the 1940s (De Haas 1938; De Jong 1984, 449-511). During the Japanese occupation (1942-1945)

\footnotetext{
5 In 1929, $75.1 \%$ of exports still consisted of tropical agricultural commodities. In 1938 this had declined to $64.7 \%$ (Boeke 1940a II, 1).
} 
the acreage of tropical cash-crops was diminished in favour of products for local consumption and army food supplies. The aftermath of the war and the consequent war of independence (1945-1949) led to massive damage of Dutch possessions as well as postponed re-investments. These losses were partly compensated in the 1950s, especially due to the commodity price boom caused by the Korean War (van der Eng 2010), but the revival was short-lived. As we will see below, rates of return to FDI in the 1950s were negligible compared to the 1920 s.

There are at least two channels of 'colonial control' that supported Dutch and foreign investment in Indonesian plantation agriculture. Cheap access to land has already been noted, but cheap access to labour was arguably the most important factor. The large-scale re-location of Belgian plantation companies from the Belgian Congo to the Netherlands Indies in the 1910s and 1920s was not because of a lack of land, but because the recruitment of labour in the Congo proved much harder than in Indonesia. ${ }^{6}$ After the abolition of the cultivation system, mandatory labour services remained in place, being mediated by more informal practices of recruitment via village chiefs (Breman 1983, 23-25; Houben and Seibert 2013, 181). Meanwhile, the population of Java was growing rapidly from c. 19 million in 1880 , to 28 million in 1900 and 61 million in 1930.

In the lowly populated outer islands of the Indonesian archipelago the Dutch government encouraged the immigration of coolie labour from China and India, which they controlled by the so-called 'penal sanction'. This law gave employers legal backing to punish contract breach by indentured workers (Thee 2013). Child labour was widely applied and labour unions were prohibited. Social security provisions were absent and labourers could be sent back to their villages in slack periods (Boeke 1940a, b I, 138-148). When labour policies were relaxed in the 1930s, the proletariat was sufficiently large to introduce major wage cuts to renege the effects of the economic depression. The Dutch colonial government also expanded its use of labour corvée services. In the 1920s about 2-3 million workers were obliged to work for the state, for an average of ca. 18-24 days. It is unsure how much of this labour was re-allocated to private companies, but it is hard to believe that it did not occur at all. The International Labour Organization made a serious investigation of the situation of labour corvée in the Netherlands Indies as part of a larger program to ban not the labour services as such, but especially the use of this tax instrument for private purposes (ILO 1930: 237-39). ${ }^{7}$

Investors in the Belgian Congo could never hope to engage so many people for rubber and palm-oil cultivation, no matter how much coercion they would apply. The officially privileged sectors such as cotton and (copper) mining all competed for the same scarce factor. Clarence-Smith (2013) has argued, in addition, that Dutch policies with regard to smallholder production of rubber and other cash-crops were far more relaxed than in the Congo, which contributed enormously to the expansion of productive capacity. The differences in policy with respect to smallholder

\footnotetext{
${ }^{6}$ Indonesian soils were highly suitable for tropical cash-crops (volcanic soils with abundant rainfall and favorable temperatures), but according to Clarence-Smith growing conditions in the Belgian Congo were not unfavorable either (2013: 194-196). In his comparison of the province of Para in Brazil with Malaysia, Forbin (1943: 100) does note an ecological advantage for the latter country.

7 We thank Marlous van Waijenburg for pointing us to this source.
} 
cultivation can only be understood in the context of different competitive pressures for scarce labour resources. Colonial investors benefitted from the rise of the smallholder sector by offering plantation companies extra volumes for trade margins.

As we will see below, European investors in plantation agriculture in the Netherlands Indies indeed obtained a decent profit. To be sure, part of this was facilitated by the interventions of the Dutch colonial state in the markets for land and labour. However, it would be too easy to conclude that this all stemmed from colonial coercion. The rates of return to colonial FDI may also have signalled a substantially higher risk-premium for two reasons that we will elaborate further below: the volatile nature of primary commodity markets and the loss of investments due to the long-term instability of the colonial project. While the risk of independence revolts may not have guided investor's decisions in the 1920s, it is clear that investors stood at a large distance, and that information asymmetries between the firms operating in Indonesia and the suppliers of capital, were high. The risk of instant capital evaporation turned into reality in the 1940s and 1950s.

\section{Returns to FDI in the Netherlands Indies: methods and estimates}

The data and methods that have been used in previous estimates of returns to FDI in the Netherlands Indies after 1900 all suffer from major flaws. A first category of studies has computed the ratio of total annual dividend payments to the total stock of FDI. The most famous example is the study by Derksen and Tinbergen (1980 [1945], 226). For the year 1938, which they hold to be a 'normal' year, they estimated a total amount of dividend and interest payments of 155 million guilders, on a Dutch FDI stock of 3.975 billion, translating into a return on investment of $3.9 \%$ (see also Baudet 1980 [1975], 252). van der Zwaag (1991, 79) has offered additional estimates for 1900-1912 (6.5\%); for 1922-1929 (7\%) and for 1930 (3.2\%) showing that the Derksen-Tinbergen figure was a lower-bound figure, but he does not explain how he obtained his estimates. Haccoû (1961 [1984], 263) reports an annual average of $6.7 \%$ for the period 1924-1939. Weijers (1941, 305-306) reports a guesstimate of 6-7 \% without defining the period.

Apart from a lack of transparency on the data and estimation methods, the idea of taking dividends over total FDI itself is highly problematic, because estimates of total FDI stock are flawed. Whereas dividend and interest payments constitute an annual flow which have been recorded in the annual balance of payments reports, the measurement of FDI stock requires an estimation methodology that takes accumulation and depreciation over time into account. van der Eng (1998a, 14-24) has pointed out that the neglect of profits being ploughed back into FDI stock has led to seriously underestimated denominators. He suggests that the observed inflow of private capital was only about one-third of the total replacement value of Indonesian FDI. Taking re-invested profits into account, van der Eng has reestimated the ratios of dividend income to total FDI as well as the ratio of remitted dividends, profits and interest payments to total FDI. He reports for the dividend/ FDI ratio $6.6 \%$ (1922), $2.8 \%$ (1930), $6.8 \%$ (1937) and for the remitted income/ 
FDI ratio $6.9 \%$ (1922), $2.7 \%$ (1930), $5.6 \%$ (1937), $2.8 \%$ (1939). Based on these estimates he concludes that "the returns to the actual amounts of foreign capital invested in Indonesia were not extraordinarily high" (van der Eng 1998a, 23). van der Eng's study certainly is an improvement, but only for a few benchmark years.

A second category of studies takes the ratio of dividends over the initial nominal stock value of companies as reported in several business and trade registers. The basic intuition is to compare the actual amount of dividends with the initial capital value of the company in order to calculate the rate of return for investors. Bosch used the dividends reported in the Van Oss Effectenboek for 26 companies for 1870-1900 and 40 companies for 1900-1940. Bosch (1948, 79-81, 605 and 681-684) reports an arithmetic average of dividend-capital value ratios of $13.55 \%$ for the entire period of 1900-1938 and breaks this down into sub-periods: 1900-1909 (11.46\%), 1910-1919 (18.35\%), $1920-1929 \quad(20.05 \%)$ and 1930-1938 (4.08\%).

However, there are several major flaws in this procedure. Since stock prices tend to be volatile, a single price quotation is unlikely to reflect the actual value of a company very well. Moreover, whenever companies re-invest profits instead of paying dividend, the increased value of the company will be absorbed in the stock price. Hence, a proper estimate of returns to investment over a given period of time should always include capital gains ánd capital losses. To justify the assumption that stock prices reflect the 'real' value of FDI, one has to work with a moving average share price based on a time-series of price quotations, instead of a single initial price observation. Moreover, by calculating annual dividend over the initial nominal stock values, Bosch' estimates fail to take the effects of inflation into account. One could argue that in the period up to 1914, modest inflation rates may not have driven a large wedge between initial stock prices and real-time deflated prices, but for the interwar era it will give highly overestimated rates of return. Bosch $(1948,97)$ was well aware of these shortcomings, including the fact that he applied no weighting scheme for companies, and invited scholars to make more precise calculations.

A third category of studies takes the ratio of dividends over some type of temporal average of stock values. The underlying idea is that stock prices absorb relevant market information and hence reflect the actual value of invested capital, that is, the present value of all expected future cash flows, with a greater degree of accuracy than estimates of total FDI stock. ${ }^{8}$ The estimates offered in the report of the Keyser \& Zonen Bank (1937), a source that Gordon (2010) uses for his calculations of total colonial surplus - but fails to discuss in detail, are based on a selection of the 60 best performing stocks at the Amsterdam stock exchange, which is understandable for a banker who wants to sell stocks, but introduces selection bias for historians interested in average rates of return. Keyser \& Zonen have split their sample into various sectors of the colonial economy as shown in Table 1.

\footnotetext{
8 There is a huge literature on how information translates into prices. One can distinguish three versions of the so-called "efficient market hypothesis": weak, semi-strong and strong. The first ("weak") states that all past publicly available information is reflected in prices, the second ("semi-strong") asserts moreover that prices immediately react to any new public available information, and the third version ("strong") states that prices even respond to hidden information (Brocquet et al. 1997, 245).
} 
Table 1 Returns on investment by industry calculated by Keyser \& Zonen

\begin{tabular}{lllll}
\hline Sector & \multicolumn{2}{c}{ "Real" returns } & & \multirow{2}{*}{$\begin{array}{c}\text { "Nominal" returns } \\
1906-1936\end{array}$} \\
\cline { 2 - 3 } & $1919-1929$ & $1930-1936$ & $1919-1936$ & 1906 \\
\hline Tin & 12.62 & 2.58 & 8.71 & 21 \\
Tobacco (Sumatra) & 12.55 & 2.1 & 8.48 & 30.5 \\
Sugar & 11.76 & 4.02 & 8.73 & 28.8 \\
Oil & 11.27 & 6.07 & 9.23 & 21.9 \\
Other tropical products & 10.77 & 5.01 & 8.53 & 17 \\
Tea & 10.03 & 4.93 & 8.04 & 17.8 \\
Tobacco (Java) & 8.48 & 3.04 & 6.36 & 18.1 \\
Rubber & 8.37 & 2.35 & 6.03 & 9.8
\end{tabular}

Source: Keyser \& Zonen $(1937,8)$. See also the references to this source by Bosch $(1948,605)$ and Gordon $(2010,438)$

"Nominal" in Keyser \& Zonen terminology means dividends paid as a ratio of the initial nominal value of the stock. "Real"refers to the average dividend income as a ratio of the average share prices over the indicated period $(1937,6)$

The real rates of return reported by Keyser \& Zonen are based on the arithmetic averages of dividend payments divided by the arithmetic averages of the highest and the lowest stock price quotation in the selected periods. This gives a more reliable result than taking initial nominal share values, but it remains a fairly weak proxy since the peaks and troughs caused by serious market shocks, are unlikely to reflect the average price trend. The more fundamental problem, however, is the exclusion of capital gains and losses. The estimates of Keyser \& Zonen, and hence the figures reported by Gordon (2010), are seriously flawed because the applied method does not allow for capital losses. Consider the following simple example: suppose we compute the arithmetic average of stock $X$ with a bottom price of 200 guilders at $t_{0}$ and a peak price of 400 guilders at $\mathrm{t}_{1}$, whereas stock $\mathrm{Y}$ peaks at 400 at $\mathrm{t}_{0}$ and ends with 200 at $t_{1}$. Both stocks paid a dividend of 30 guilders. In this case the estimated rate of return will be the same for both stocks, namely $10 \%$. However, in reality stock X yields a return of $10 \%$ plus a capital gain of $100 \%$, while stock Y yields a return of $10 \%$ and a capital loss of $50 \%$ ! Indeed, with this method one can never incur a negative rate of return (see Table 1). Moreover, the "real" returns presented by Keyser \& Zonen are not "real" in the usual economic sense. They have not been adjusted for inflation, a fact entirely overlooked by Gordon (2010).

\section{New data, new method, new research agenda}

\subsection{Data}

Thanks to years of intensive data entry and elaboration efforts starting in 1999, the Studiecentrum voor Onderneming en Beurs (SCOB) of Antwerp University, has constructed a database of official monthly price lists of the Brussels Stock Exchange (BSE hereafter) going back to 1832 . The SCOB database contains hand collected 
end-of-month prices, numbers of shares and bonds, dividends and interest rates as well as ex-dividend day and all information on capital operations (stock splits, reverse splits etc.). All the data were obtained from the official quotation lists and checked in secondary sources, primarily the so-called Recueil Financier. ${ }^{9}$ This dataset is unique in terms of its coverage (all traded stocks), its detail (monthly prices) and its accuracy (cross-checking with secondary sources). In fact, digitized official price lists of stock exchanges, including, unfortunately, the Amsterdam stock exchange (AEX), are virtually non-existent.

From the SCOB database we have derived 17 international companies that had concentrated their investments primarily or exclusively in the production of tropical agricultural commodities in the Netherlands Indies (see "Appendix" for the companies included). Brussels was a major centre for international stock trading in the late 19th and early 20th century, mediating an impressive amount of FDI in all corners of the world, from China to Argentina and from Brazil to Egypt. Stocks of foreign companies based in the Netherlands Indies became listed at the BSE from 1913 onwards. The Soengei Lipoet Cultuur Maatschappij was the first, but in due time several others were listed.

Although the 17 companies in our sample vary in size and in type of plantation production and commercial activity, we cannot take full 'representativeness' for granted. The sample is likely to be sufficiently large and diverse to offer a proxy of the foreign business performance in Indonesian tropical agriculture, but the sample is small compared to the 138 companies listed at the Amsterdam stock exchange in 1938, and they are just a fraction of the ca. 2850 companies that were active in the Netherlands Indies in 1930 (Lindblad 1993, 703). Our sample includes companies that invested in tropical agricultural commodities such as rubber, palm oil, coffee, cocoa and tea. The majority of companies had a portfolio dominated by palm oil and even more so by rubber. In a way this is good news, because these two crops were by far the two most important products of the plantation sector. We have excluded FDI in tin (e.g. Billiton) and oil (Royal Dutch) because these companies were not listed at the BSE (Royal Dutch only from 1928 onwards) and operated on a global scale. A considerable part of the companies in our sample were linked to a few Belgian-French investment groups, most notably Bunge and Hallet/Rivaud, ${ }^{10}$ who also invested part of their capital in plantation agriculture in the Belgian Congo, but via different subsidiaries. ${ }^{11}$

Due to their domestic reputation in Belgium these firms were able to tap into the Belgian capital market. They had direct links with the Belgian royal family and were regarded as first class investors, with great 'expertise' in colonial enterprise. For example, Adrien Hallet [1867-1925] was an agronomical engineer of the University of Gembloux (Belgium), who realized numerous investments in the Netherlands Indies, the Belgian Congo, Malaysia and French Indochina. His knowledge of

\footnotetext{
9 The 'Recueil Financier' was an annual monograph providing extensive information about all stock quoted companies, including administrators, production, capital changes, dividends and balance sheets.

${ }^{10}$ On Hallet and Bunge see Kurgan-van Hentenryk (1996) and on Rivaud see Boucheret (2010).

11 Osterrieth was also active in a few companies, but we excluded other companies such as Compagnie de l'Hévéa, Sipef, Banque des Colonies and Socfin, because of their large operations in other countries.
} 
tropical products made him a much demanded person on many boards of directors. He also participated in the establishment of a colonial bank in 1919 (Banque des Colonies). When he suddenly died in 1925, his son, Robert Hallet [1900-1947] took over. Edouard Bunge [1851-1927] was one of the directors of Abir and Anversoise, two rubber companies which were both founded in 1892, and exploited the wild rubber royal domains of Leopold II. Bunge was rooted in the Antwerp business community and also diversified his activities to many other countries such as Argentina and Malaysia. At present, Bunge is one of the biggest agro-business companies in the world quoted at the New York stock exchange. If these stockquoted companies have been more efficient in setting up colonial enterprises and/or managing complex investment portfolios, there may be reason to believe that our sample offers an upper-bound estimate of the rate of return to colonial FDI.

We can also compare our sample to the colonial companies listed at the AEX, by using the lists provided by van der Zwaag (1991, 304-310). This shows that $85.5 \%$ of the companies was engaged in tropical agriculture, $7.1 \%$ in trade and $4.6 \%$ in oil and other types of mining. Unfortunately, van der Zwaag's lists do not allow us to sub-divide tropical agriculture, since many companies entered under the general name of "cultuurmaatschappij". Using only the companies that had a clearly specified name, suggests that Dutch firms were active in a wider range of products, including rubber, coffee, forestry, sugar, tea, kina, rice, tobacco and palm oil. That said, rubber and palm oil were by far the biggest cash-crops in Indonesian exports and have arguably driven profits of Dutch colonial companies to a very large extent, as they did with the profits of the companies in our sample.

Since the BSE was closed during the German occupation of Belgium in 1914-1918, complete and consistent price lists for our sample are only available from 1919 onwards. This motivates the starting year of our analysis. During the German occupation of Belgium in the Second World War, Netherlands Indies stocks were not listed from the 10th of May 1940 to the end of August 1942. Thereafter only part of the sample was listed again and we use this reduced sample to extend our estimates into the war years and the post-colonial era up to 1958, but for consistency purposes we focus our interpretation on the period 1919-1938. ${ }^{12}$

\subsection{Method}

The advantage of using consistent series of monthly price observations is that it allows us to compute real rates of return to foreign investment in tropical agriculture in the Netherlands Indies with a much greater degree of precision than previous studies have done. Following the Dimson-Marsh-Staunton (DMS) method, which is the current standard for international comparisons of investment returns (Caporin et al. 2013, 1-26), we calculated the geometric annual average rate of return on colonial company stocks. We deflated these estimates using the official

\footnotetext{
12 On 31/8/1942 the following stocks were listed again: Huileries de Sumatra (action de capital), Huileries de Sumatra (part de fondateur), Plantations de Johore (action de capital), Plantations de Johore (part de fondateur), Nord de Sumatra (action de capital), Nord de Sumatra (part de fondateur). Others (like Société des Plantations de Telok-Dalam) would be listed only in 1945 or even in 1947 again (like Soengei Lipoet Cultuur Maatschappij).
} 
Belgian CPI-index of the Ministry of Economics to obtain real rates of return. The core assumption is that share prices absorb all relevant market information available, including profits set aside for re-investment (i.e. capital gains).

Of course, in a world with imperfect market information, stock prices will never reflect the real value of invested capital at any particular moment in time, but by using monthly data of capital gains and dividend yields over a 20-year time period we ensure the inclusion of sufficient points of comparison to make reliable calculations of investment performances, evening out short-run market volatility. Although we report figures for the whole period of 1919-1938, we also show shorter sub-periods to indicate how sensitive results can be to yearly fluctuations (another factor that has burdened previous studies). For the sake of comparison we will present geometric and arithmetic average returns, but given the volatility of the price data we use the geometric mean (GM) for our historical interpretation.

We calculated Laspeyres' market-capitalisation weighted price and return indices by linking monthly returns in a chain index. This index reflects the value of an investment of BEF 100 in all stocks at the beginning of the indicated period and is adjusted on a monthly basis through reinvestment in all stocks available during the next period. The total return index at the end of the period reflects the end value of an investment made in stocks. As dividends were partly paid in Dutch guilders we converted dividends into BEF (as stock prices were quoted in BEF only), using the exchange rates published in the official lists. Based upon these indices, periodic rates of return can be calculated for any desired period. In mathematical terms the indices are constructed as follows:

$$
I_{t}=I_{t-1} \cdot\left(1+\sum_{i=1}^{L_{t-1}} w_{i t-1} r_{i t}\right)
$$

where $I_{t}$ denotes the value of the index at the end of period $t$ where $w_{i t-1}$ is the weight attached to stock $i, L_{t-1}$ the number of stocks at the end of period (month) $t-1$, and $r_{i t}$ the return of stock $i$, including paid dividends (if there were any). We set $I$ equal to 100 at the beginning of each period. Our weights refer to relative market capitalisations:

$$
w_{j t-1}=\frac{P_{j t-1} N_{j t-1}}{\sum_{j=1}^{L_{t-1}} P_{j t-1} N_{j t-1}}
$$

where $P_{j t-1}$ is the price of stock $j$ at $t-1$ and $N_{j t-1}$ is the number of stocks for stock $j$ at $t-1$.

The DMS method includes some other widely accepted principles in finance. First, total returns are calculated under the assumption that investors reinvest dividends at ex-dividend day. Second, all necessary adjustments for capital operations are made (stock splits, bonus shares, reverse splits, attribution and inscription rights). Third, we include common stocks only, excluding 'special' types of stocks granting exclusive voting rights and dividend privileges to an elite group of shareholders. We get back to this latter point in Sect. 7. 


\section{Stock price indices, 1916-1940}

We start by showing the price indices of our sample in Figs. 1 and 2 in respectively current (nominal) and constant (real) index values $(31 / 08 / 1916=100)$. Figure 3 compares the real price index of the Netherlands Indies (Fig. 2) with the all share stock price index of the BSE $(31 / 12 / 1918=100)$, which serves as a proxy of price trends on the major European stock markets.

Figures 1 and 2 show the enormous gap between the nominal stock price index and the real (inflation-adjusted) stock price index. The gap rose to a factor 3.5 within a decade after 1916 and when considering the full period 1916-1940 nominal capital gains went up from 100 to 668 , while real capital gains rose to 147 . The real price index presented in Fig. 2 clearly reflects the upturn of the world economy during the 1920s, followed by the worldwide collapse of stock markets during the late 1920s, the period of depression in the early 1930s and the subsequent recovery of world markets. Following on this point, it should be noted that the real stock price index deviated from the European trend (as proxied by the BSE index) in a few important respects. Figure 3 shows that the price index of colonial companies was more volatile, with higher peaks and deeper troughs. The larger degree of diversification in the BSE all shares index has a dampening effect on price shocks. But the higher volatility also reflects the more volatile world market conditions for agricultural commodities, and tropical cash-crops in particular. The stock prices of the colonial companies started to rise earlier and more spectacularly than the BSE index in the 1920s, but underwent a major correction in 1927, long before the collapse associated with the international stock market crash of 1929. The recovery

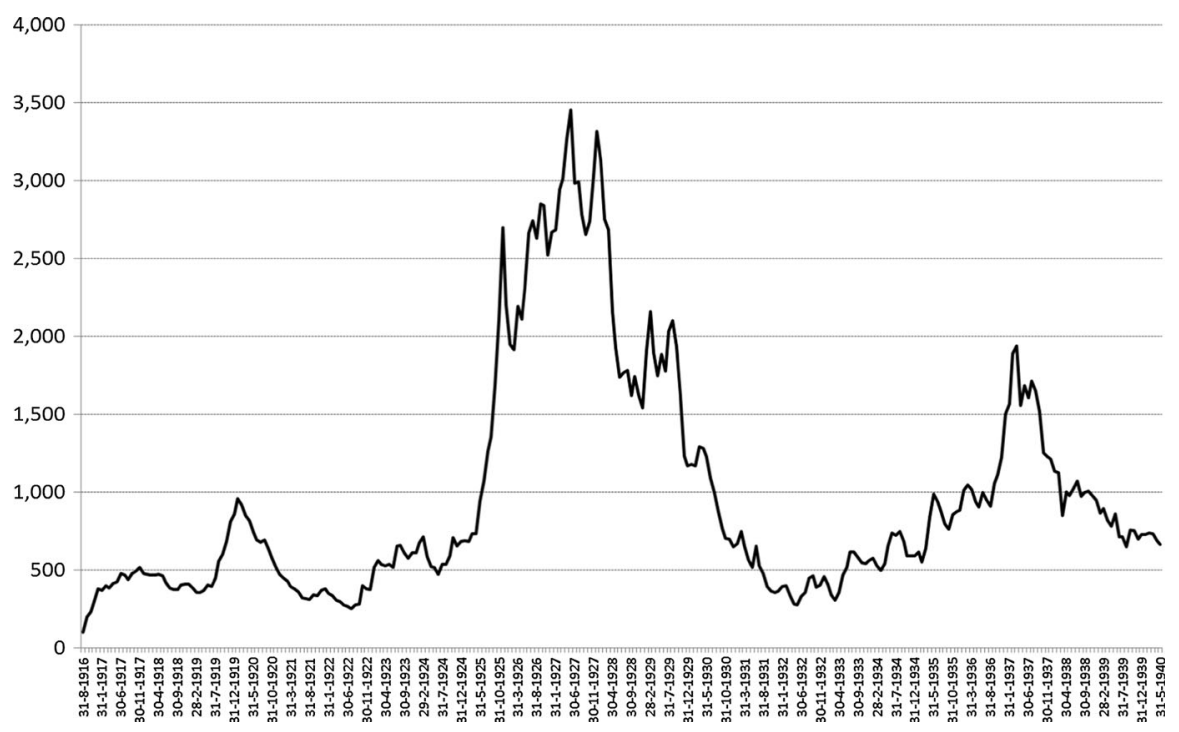

Fig. 1 Nominal price index of BSE quoted companies active in the Netherlands Indies, August 1916May $1940(1916=100)$. Source: Cours authentique de Bruxelles, monthly prices adjusted for capital operations 


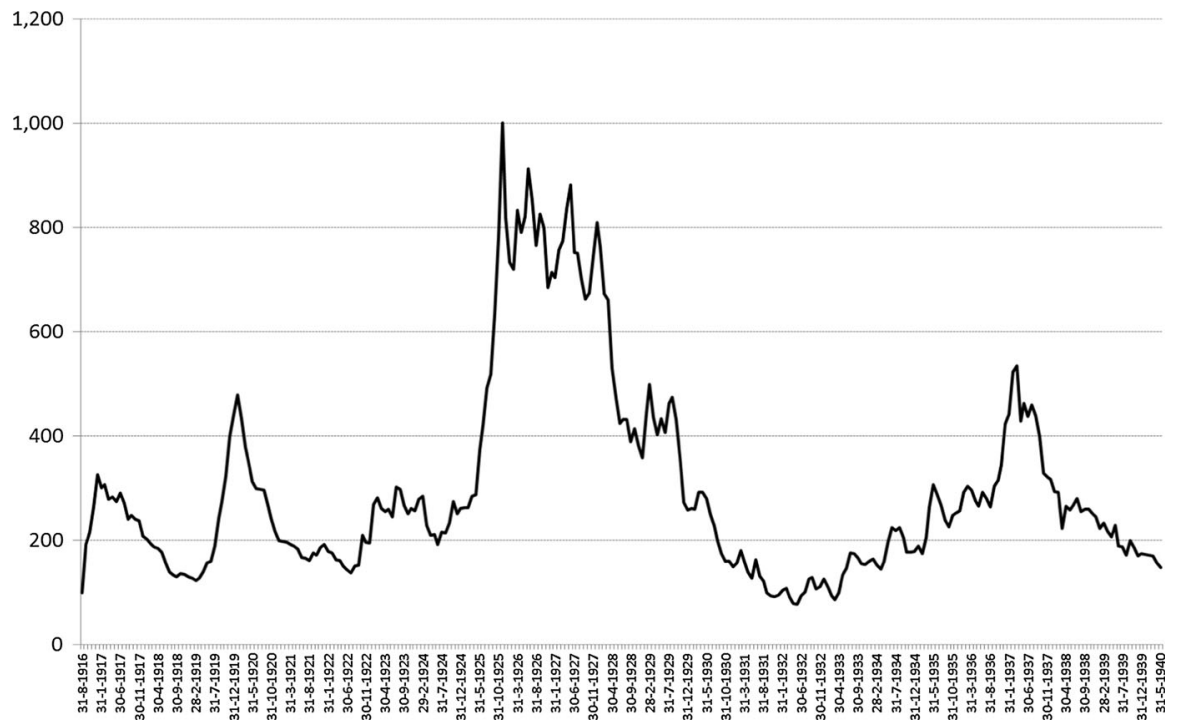

Fig. 2 Real price index of BSE quoted companies active in the Netherlands Indies, August 1916-May $1940(1916=100)$. Source: Cours authentique de Bruxelles, monthly prices adjusted for capital operations

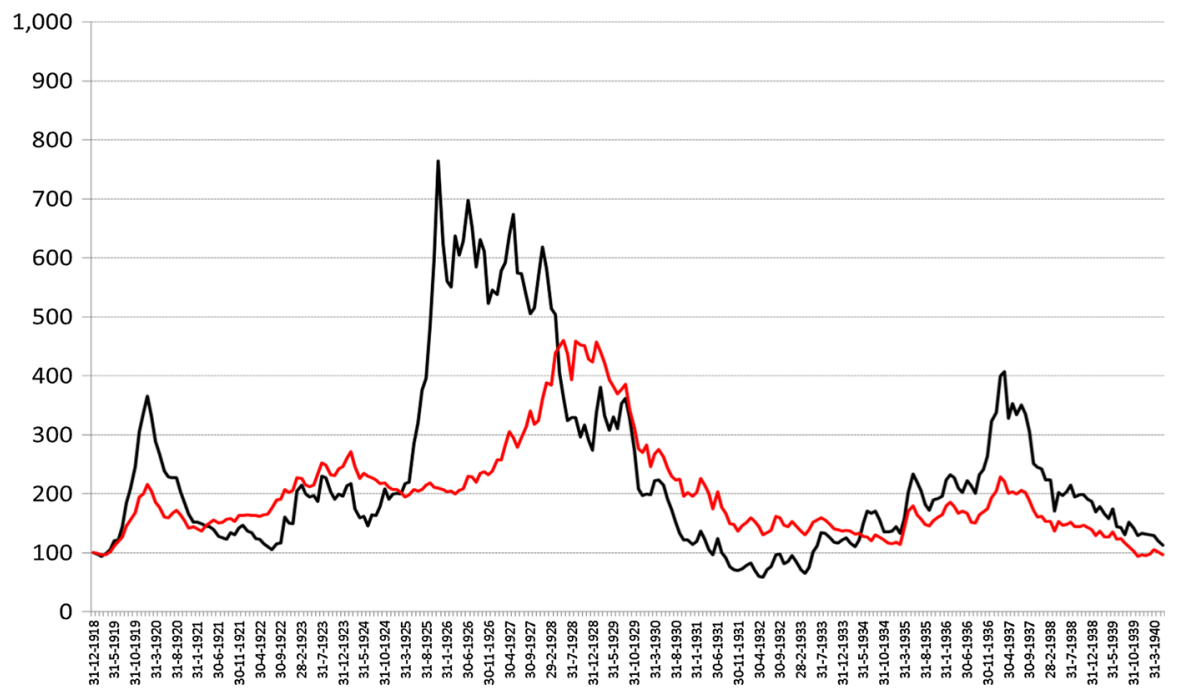

Fig. 3 Real stock price indices of BSE quoted companies active in the Netherlands Indies and the all share BSE index, December 1918-May 1940 (1918 = 100). Source: Cours authentique de Bruxelles, monthly prices adjusted for capital operations

in the 1930s was again stronger than the BSE index, reflecting a more rapid recovery of investor's confidence in the Indonesian plantation sector, than the West European economy in general. 
A comparison on Figs. 2 and 3 reveals that capital gains were considerably lower in the period of 1919-1939, than in the period 1916-1939. Most of the spectacular rise in the mid-1920s and mid-1930s had been evaporated in the late 1930s. The monthly average of 1919 was 225, which was already double the value of August 1916. In May 1940 the index was below this value, at 147. This underlines how sensitive estimates are to the selection of start and end dates. During the First World War large inventories of commodities had been built up in the Netherlands Indies, which could now be sold at high world market prices (Bosch 1948, 290). Favourable investors' prospects led to at least 170 new companies being founded in 1920 (Lindblad 1993, 704). Sugar, for example, sold at $5.25 \mathrm{fl} / \mathrm{pikol}^{13}$ in July 1918, but this price peaked at $66 \mathrm{fl} / \mathrm{pikol}$ in May 1920; Robusta coffee rose from $16.12 \mathrm{fl} /$ pikol (July 1918) to $76.25 \mathrm{fl} /$ pikol (November 1919) (Gonggrijp 1957, 159). Consequently, the nominal stock price index starting at 100 in August 1916 rose to a level of 959 in January 1920. The price explosion for tropical agricultural commodities did not last long, however. The subsequent depression of 1920-1921 drove prices down, which compounded the extremely volatile nature of international rubber prices in the immediate post-war years.

As rubber trees have to be planted years before they reach maturity, the risk of serious over- or under-production in this sector is inherently large. Prices for rubber went down from about 27.5 pence per pound in 1918 to 10.5 pence in 1921, reaching a low of 6.75 pence on the 30th of August 1922. This price collapse raised the call for the implementation of production and export restriction schemes (Hexner 1946, 280-293). As the Dutch refused to comply with the Stephenson restriction scheme initiated by the British in 1922, the Netherlands Indies were in a good position to 'free ride' and raise production. Indonesian exports rose from 103,000 $\mathrm{t}$ in 1922 to 228,000 $\mathrm{t}$ in 1928 (Allen and Donnithorne (1962) [1954], 123).

However, the rising rubber prices also provoked serious frictions with the main consumer, US industries, who severely contested the restriction scheme (Forbin 1943, 155; Brandes 1962). As a result, American companies scaled up their investments in rubber plantations during the 1920s, for instance in Brazil (by Ford), in Liberia (Firestone), in the Philippines (Goodyear Tire and Rubber Company) and also in the Netherlands Indies (US Tyre Company). The expansion in rubber production capacity resulted in huge oversupplies when the market for rubber weakened in the late 1920s. In 1928 when the Stephenson plan was ended, the prices were already in decline, but of an average price of $10 \frac{1}{4}$ pence in 1929 barely $2 \frac{1}{4}$ pence was left in 1932 (Forbin 1943, 88).

During the 1930s all tropical agricultural commodities were hit extremely hard. It forced the Dutch government to commit to the International Rubber Regulation Agreement in 1934, regulating about $98 \%$ of world exports in rubber. Collapsing palm oil prices during the Great Depression did not result in international market coordination. Nevertheless, the Netherlands Indies managed to become the main exporter of palm oil to the United States, which is all the more remarkable given the maintenance of the gold standard until 1936, while the US and UK had gone off much earlier (Keesing 1978, 219) (Allen and Donnithorne (1962) [1954], 139-145)

131 Pikol is equivalent to $61.76 \mathrm{~kg}$. 
and Japan devaluated the yen even with $60 \%$ (Gonggrijp 1957, 186). Indonesian exports plummeted "under the leaden load of the golden florin" (Prince 1996, 66). As balance of payments reports show, the remitted profits on foreign capital were over 275 million guilders in 1925, 190 million guilders in 1930, but dwindled to just 26 million guilders in 1933 (Vandenbosch 1938, 332-333). Dividend payments stopped and company profits were only restored to levels approaching the pre-crisis years in 1938, when they reached 167 million guilders (Tinbergen and Derksen 1980 [1945], 521). Meanwhile, the Dutch government switched to a protectionist policy that restricted the import of cheap Japanese products in the colony, in favor of high-priced Dutch products (Dick 1989). Commodity prices revived in 1936-1937. With the outbreak of the war in Europe the Netherlands Indies benefitted briefly from the high demand for tin, rubber and oil, allowing them to replenish their sterling balances (Allen and Donnithorne 1962 [1954], 37), but the Japanese invasion of 1942 ended the game.

\section{Returns to colonial FDI, 1919-1958}

Table 2 presents our estimates of the nominal and real rates of return on investment in four decades, i.e. 1919-1928, 1929-1938, 1939-1948 and 1949-1958. The first decade captures the 'roaring' twenties, the second decade captures the great depression and its aftermath. The third decade captures the war years, including the

Table 2 Total returns to investment of BSE quoted companies active in the Netherlands Indies, 1919-1958

\begin{tabular}{|c|c|c|c|c|c|c|c|}
\hline & \multicolumn{3}{|l|}{ Real } & \multicolumn{3}{|c|}{ Nominal } & \multirow[t]{2}{*}{ Dividend yield } \\
\hline & GM & $\mathrm{AM}$ & STDV & GM & $\mathrm{AM}$ & STDV & \\
\hline 1919-1928 & 14.3 & 41.2 & 59.0 & 17.2 & 36.9 & 58.3 & 2.7 \\
\hline 1929-1938 & -2.8 & 3.9 & 40.1 & -3.5 & 2.9 & 42.2 & 1.3 \\
\hline 1939-1948 & -22.6 & -16.7 & 35.2 & -11.4 & -7.7 & 27.6 & 0.6 \\
\hline 1949-1958 & 0.3 & 4.2 & 25.9 & 1.7 & 5.6 & 26.3 & 3.3 \\
\hline 1919-1936 & 8.9 & 27.4 & 52.2 & 9.3 & 24.0 & 53.1 & 1.7 \\
\hline 1919-1938 & 5.4 & 22.5 & 51.0 & 6.3 & 19.9 & 51.8 & 2.0 \\
\hline 1919-1939 & 4.0 & 20.5 & 50.4 & 4.9 & 18.1 & 51.0 & 2.0 \\
\hline 1921-1939 & 1.7 & 12.7 & 46.0 & 4.4 & 16.3 & 49.9 & 2.0 \\
\hline 1919-1924 & 15.5 & 38.9 & 54.3 & 11.0 & 21.5 & 51.7 & 1.9 \\
\hline 1919-1925 & 33.9 & 65.4 & 64.2 & 30.0 & 52.1 & 64.1 & 2.3 \\
\hline 1919-1926 & 30.1 & 58.1 & 59.1 & 29.6 & 49.0 & 58.5 & 2.6 \\
\hline 1919-1927 & 26.7 & 51.9 & 56.1 & 29.7 & 46.9 & 55.5 & 2.9 \\
\hline 1919-1928 & 14.3 & 41.2 & 59.0 & 17.2 & 36.9 & 58.3 & 2.7 \\
\hline
\end{tabular}

Source: own calculations based on SCOB database of BSE monthly stock quotations

$G M$ geometric mean, $A M$ arithmetic mean, $S T D V$ standard deviation. Each period in this table refers to the first trading day of the starting year and the last trading day of the end year. All estimates are based on monthly re-adjusted data, market cap weighted, common stock only 
Indonesian war of independence ending in 1949. The fourth decade covers the years up to the nationalization of Dutch assets. Table 2 also shows the results for longer and shorter periods in the second and third row blocks.

During the first decade of 1919-1928 investors were able to realize an impressive annual rate of return of $14.3 \%$. This high rate resulted mainly from the capital gains realized from the start of 1922 up to 1927. As already pointed out above, these results are dependent on the exact time period chosen. For 1919-1924 the (geometric) average is $15.5 \%$, but it increases to an incredible $33.9 \%$ by adding one more year, and from then on it decreases to $30.1 \%$ (1919-1926), $26.7 \%$ (1919-1927) and $14.3 \%$ (1919-1928).

The rates of return during the second decade of 1929-1938 were dominated by the world economic depression of the 1930s, which hit the export sector of the Netherlands Indies particularly hard. During the third decade 1939-1948, the results worsened with a negative total return of $-22.6 \%$. These losses were not recovered in the fourth decade of 1949-1958, especially because this period ended with the nationalization of Dutch assets. The rate of return of $0.3 \%$ stood in sharp contrast to the rates of return of Malaysian-based companies, which recovered from the second World War much better.

In Fig. 4 we compare the annual real rates of return to the stocks of the companies in our sample (i.e. the BSE sample) with the world market prices for palm-oil and rubber derived from the Sauerbeck series of wholesale prices for the period 1916-1944 $(1916=100)$, in order to explore the relationship between the prices for these commodities and the rates of return to FDI in these sectors. What becomes clear is that price trends for rubber were roughly consistent with the indextrend of the BSE sample, but that these can by no means account for the magnitude of the trend in the rates of return, certainly not when one takes into account that we report nominal prices here. This tells us that investors, as one would expect, have mainly responded to trends in output (and exports) and in particular the production expansion of the firms they invested in, rather than directly observed world market price trends. It also reflects the fact that this expansion of production in the 1920s and the overcapacity that it generated in the late 1920s, had a considerable depressing effect on world market prices.

Shifting attention to the full interwar period we see again how sensitive the estimated returns are to the timing of start and end dates: for 1919-1939 the total rate of returns stick to about $4.0 \%$, while for 1919-1938 the return is $5.4 \%$ and for 1919-1936 even $8.9 \%$. These differences stem from the large volatility in stock prices. Stock values experience a "standard" degree of volatility of ca. $17.5 \%$ around a long-term moving average (Dimson et al. 2013, 12), but in our sample we observe a volatility of over $50 \%$ for 1919-1939. This is consistent with the literature on international trade, showing that rural economies with a low degree of diversification tend to cope with the economic and political backlashes of volatility to a much larger extent than industrialized economies (Williamson 2008, 2012). Given the high-risk profile of colonial FDI in Indonesia, the above average rates of return for the interwar era may thus partly be ascribed to a higher risk-premium.

Given the high risk profile of these investments, most of the companies in our sample used to follow dividend policies that would amortize their capital as soon as 


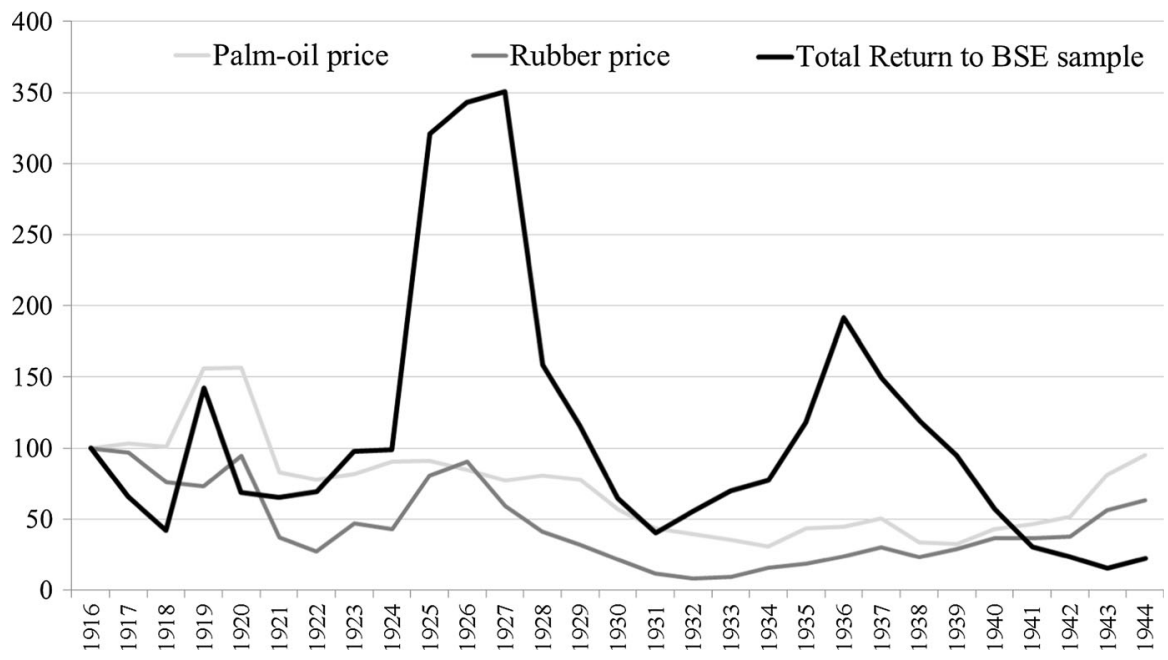

Fig. 4 Annual real stock price indices of BSE quoted companies active in the Netherlands Indies and nominal world market prices for palm-oil and rubber, 1916-1944 (1916=100). Source: Cours authentique de Bruxelles, annual prices adjusted for capital operations. World market prices for palm-oil from Sauerbeck (1845-1950); rubber prices from US Bureau of the Census (1975) Historical Statistics of the United States

possible, reserving large shares of profits for re-investment (van der Eng 1998a, 19). If dividends were paid out, which was often not the case, they were modest. ${ }^{14}$ Dividends around $2 \%$ were also considerably below the international historical average yields of around $4.1 \%$ (Dimson et al. 2013, 31). The rising stock prices in the 1920s were thus largely supported by the dividend policies adopted by these companies.

Finally, it is worthwhile to dig a bit deeper into some of the distributional aspects of dividend payments which have not received much attention in the literature. Up to here, we have only considered the rates of return to common stock, but there were also dividends paid to special stocks. The most typical example were the 'founder stocks', or so-called "parts de fondateur". ${ }^{15}$ While common stock could be issued without limitation, the issuing of founder stocks was restricted to a maximum. In the official statutes of companies issuing founder stocks a split of profits was provided in case profits would exceed a threshold (usually 4-5\%). A share of the profit would be kept for legal reserve purposes (often $10 \%$ ), a share as a bonus to the board of directors (often $10 \%$ ), while the remaining share of profits would be distributed equally over a large number of ordinary shareholders and the much smaller number of founder shareholders. Moreover, while ordinary shareholders had to buy stocks, the "parts de fondateur" were mostly issued for free as a compensation for the efforts of the founder or the transfer of assets (e.g. concessions) at an overvalued price. As the "multiple voting right" system that

\footnotetext{
14 According to Lindblad $(1998,82)$ only $16 \%$ of all firms paid dividends in $1914 ; 24 \%$ in 1930 and $21 \%$ around 1940.

15 See on "founder capital" also à Campo $(1996,80)$.
} 
prevailed at the time was often reserved to the founders of a company, the owners of founder stocks were also in a position to decide about dividend payments. ${ }^{16}$

The Huileries de Sumatra, founded in 1911 with headquarters in Brussels, offers an example. Its initial capital of 1.4 million BEF was raised by issuing 14,000 ordinary stocks of 100 BEF each. ${ }^{17}$ In August 1919 this position had risen to 8 million BEF, when two Parisian bankers, Olivier and Maurice de Rivaud, stepped in. In 1923 the stocks became listed at the BSE. Two types of stocks were available at this moment: 80,000 ordinary stocks of 100 BEF and a fixed amount of 17,500 "parts de fondateur" (Recueil Financier 1933 II, 760). All stockholders were entitled to the first $6 \%$ of profits, while the remaining profits were distributed as follows: $10 \%$ for the board of directors, $45 \%$ to the ordinary stockholders and $45 \%$ to the founder stockholders. This meant that founder stockholders got on average 2.6 times the amount of dividend paid to ordinary shareholders. Table 3 shows the net dividends per share, the total dividends and the end-of-year price for stocks of the Huileries de Sumatra.

The total sum of dividend payments in the period 1923-1939 for the ordinary shares was $12,840,000$ million BEF. The total amount paid to the founder stockholders was $7,307,300$ million BEF. This meant $63.7 \%$ for 80,000 ordinary stocks and $36.3 \%$ for 17,500 founder stocks. Hence, as Table 4 shows, the market price of founder stocks went up to a staggering $6075 \mathrm{BEF}$ in 1927 , whereas the price for the ordinary stock was 670 BEF. Since in most years dividends were above $6 \%$, bonuses ("tantièmes") were paid to the board of directors of which several members were also the owners of the "parts de fondateur". In 1927 the company made a profit of 16 million BEF (double the equity of 8 million BEF) and the board decided to put 12.7 million BEF into the reserves. From 1929 on the board changed its policy. Out of a sum of profits of 4.9 million BEF, 3.8 million BEF were reserved as "profits to be carried forward" and in 1930 the company, still making a profit of 3.3 million BEF made an additional depreciation of 5 million BEF. ${ }^{18}$

\section{Colonial FDI in international perspective}

In 2002, DMS published a seminal book Triumph of the Optimists in which they compiled data on equity investment and returns to equity for OECD 16 countries over the full 20th century. Since this publication, their dataset has been updated and adjusted on an annual basis. To compare our results for the Netherlands Indies we will use the February 2013 edition of the updated version "Crédit Suisse Global investment Returns Sourcebook 2013", which offers returns to equity for the period 1900-2012. We have summarized these data in Table 4 and added our estimates for the Netherlands Indies. We made one minor modification with regard to the

\footnotetext{
16 The multiple voting right system gave many votes for some stocks, while giving only one vote a stock to others or even no voting rights at all for certain types of stocks (Baums and Wymeersch 1999, Willems 2000).

17 To put this into perspective, the 1913 day wage of a miner (one of the best paid category of workers) was c. $5 \mathrm{BEF}$, which rose to c. $47 \mathrm{BEF}$ in 1938 (Baudhuin 1944, 327).

18 Recueil Financier 1933 II, 462.
} 
Table 3 Distribution of (net) dividends between different types of stocks of the Huileries de Sumatra (all prices in current $\mathrm{BEF}$ )

\begin{tabular}{|c|c|c|c|c|c|c|}
\hline \multirow[t]{3}{*}{ Ex-dividend day } & \multicolumn{4}{|l|}{ Dividends } & \multirow{2}{*}{\multicolumn{2}{|c|}{$\begin{array}{l}\text { Stock prices } \\
\text { On } 31 / 12\end{array}$}} \\
\hline & \multicolumn{2}{|c|}{ Per share (net) } & \multicolumn{2}{|l|}{ Total } & & \\
\hline & Common & Founder & Common & Founder & Common & Founder \\
\hline $25-6-1923$ & 8.5 & 15.5 & 680,000 & 271,250 & 195 & 502 \\
\hline 26-6-1924 & 10.2 & 23.3 & 816,000 & 408,100 & 200 & 551 \\
\hline $18-6-1925$ & 12.8 & 35.0 & $1,020,000$ & 611,975 & 425 & 1596 \\
\hline $10-6-1926$ & 13.1 & 38.4 & $1,048,000$ & 672,000 & 400 & 1425 \\
\hline $15-6-1927$ & 16.9 & 54.2 & $1,353,600$ & 947,625 & 670 & 6075 \\
\hline $18-6-1928$ & 15.9 & 50.9 & $1,272,000$ & 890,400 & 333 & 2010 \\
\hline $12-6-1929$ & 16.1 & 51.5 & $1,288,000$ & 901,600 & 265 & 1410 \\
\hline $12-6-1930$ & 9.2 & 16.8 & 736,000 & 294,000 & 159 & 900 \\
\hline $12-6-1931$ & 0.0 & 0.0 & 0 & 0 & 87 & 825 \\
\hline $12-6-1932$ & 0.0 & 0.0 & 0 & 0 & 108 & 798 \\
\hline $12-6-1933$ & 0.0 & 0.0 & 0 & 0 & 228 & 865 \\
\hline $12-6-1934$ & 0.0 & 0.0 & 0 & 0 & 244 & 825 \\
\hline $13-6-1935$ & 6.0 & 0.0 & 480,000 & 0 & 238 & 995 \\
\hline $11-6-1936$ & 9.7 & 17.7 & 773,600 & 309,400 & 433 & 1700 \\
\hline $9-6-1937$ & 17.2 & 54.9 & $1,372,800$ & 961,100 & 293 & 1230 \\
\hline 17-6-1938 & 15.0 & 41.1 & $1,200,000$ & 719,950 & 215 & 680 \\
\hline 16-6-1939 & 10.0 & 18.3 & 800,000 & 319,900 & 170 & 458 \\
\hline
\end{tabular}

Source: SCOB database, Bourse de Bruxelles, Cours authentique 1923-1939, Recueil Financier, various issues

business cycle, which was somewhat different for the industrialized countries (like Belgium) as compared to the Netherlands Indies. While keeping the DMS data as published, we stick to the periods of our sample starting 1 year earlier, that is, 1919-1928, 1929-1938 and 1919-1938.

Real rates of return exceeding $8 \%$, as observed in the Netherlands Indies from 1919 to 1936 are among the highest that investors can hope for over a period of nearly two decades. In fact, rates of $8 \%$ are hardly ever sustainable in the long run. True, the average returns over the 20th century for stocks of US-based companies computed by Dimson et al. (2002) were around $8 \%$, but this is the only economy that experienced such high returns for such a long period of time; for Europe, DMS find a real rate of return of $4.2 \%$ for the period 1900-2012, and also for the US the 1900-2012 results are considerably lower (6.3\%) as Table 4 reveals (Dimson et al. 2013).

The world average rates of return to equity were about $5 \%$, and for the world excluding the US about $4.4 \%$. For Europe the returns were $4.2 \%$. Following the assumption of DMS that the risk-free rate of return in the 20th century was on average around $3 \%$, this implies an average risk-premium of equity investments somewhere between 1.2 and 2 percentage points. Considering the whole period of 1919-1938, the total return of our sample $(5.4 \%)$ was roughly similar to the world average excluding the US (5.8\%). However, interestingly, compared to the rates of 
Table 4 DMS real returns on equity, 1900-2012

\begin{tabular}{lllll}
\hline & $1920-1929$ & $1930-1939$ & $1920-1939$ & $1900-2012$ \\
\hline Belgium & 7.3 & -5.9 & 0.5 & 2.5 \\
Netherlands & 1.5 & 2.7 & 2.1 & 4.9 \\
France & 9.2 & -3.7 & 2.6 & 3 \\
Germany & 0.5 & 2.2 & 3.9 & 3.1 \\
UK & 9.3 & 2.6 & 5.9 & 5.2 \\
US & 14.4 & 2 & 8 & 6.3 \\
Europe & 8.4 & 0.5 & 4.4 & 4.2 \\
World & 11.4 & 2.2 & 6.7 & 5 \\
World, excl. US & 8.7 & 2.9 & 5.8 & 4.4 \\
& $1919-1928$ & $1929-1938$ & $1919-1938$ & \\
Netherlands Indies & 14.3 & -2.8 & 5.4 & \\
\hline
\end{tabular}

Source: Dimson, Marsh and Staunton (2013); Own calculations for the Netherlands Indies

Copyright@2013Elroy Dimson, Paul Marsh and Mike Staunton

All geometric annual average rates of return to (a selection of) stocks traded at major domestic stock exchange. All periods from the 1st day of the start year to the last day of the end year. The different yields of the Netherlands and Germany in the 1920s and 1930s are probably due to the timing of the stock market crash in the closing months of 1929. In Germany and the Netherlands stocks lost more value before the end of the 1920-1929 period and started at lower levels in the 1930-1939 period

return in the Netherlands $(2.1 \%)$, the profitability of investing in the Netherlands Indies was considerably higher. In fact, during 1919-1928, the total returns of companies operating in the Netherlands Indies were among the highest in the world. The $14.3 \%$ (in real terms) was substantially better than the world average (11.4\%), ranking among the best performing economies of the time such as the US. However, in the subsequent period of 1929-1938, FDI in the Netherlands Indies performed under average. The negative return of $-2.8 \%$, was ca. 5 percentage points lower than the world average $(2.2 \%)$, and ca. 3 percentage points lower than the returns in Europe $(0.5 \%)$.

\section{Conclusion}

In this paper we have presented new estimates of the return on investment in the Netherlands Indies for the late colonial era (1919-1938). We used a new source of data (monthly price quotations of companies active in the tropical cash-crop sector in the Netherlands Indies listed at the Brussels stock exchange) and adopted the Dimson, March and Staunton method to calculate rates of return to equity (a real geometric annual average of total returns to investment). These returns incorporate dividends as well as capital gains (and losses) and have been adjusted for inflation.

We found that returns to FDI in the Netherlands Indies during 1919-1928 were impressive (14.3\%), but that during 1929-1938 the tides turned, with an average annual rate of return of $-2.8 \%$. Compared to the rates of return on investments in the metropole, the returns to colonial FDI were considerably higher, i.e. $2.1 \%$ for the 
Netherlands 1920-1939 versus $5.4 \%$ for the Netherlands Indies 1919-1938. The returns to FDI in the Netherlands Indies were subject to a high degree of volatility, which is consistent with the idea that specialization in basic commodities involves higher rates of risk. Moreover, in the years after 1942 investors lost most of what they had.

What do our estimates imply for the debate about the costs and benefits of empire? Obviously, we have made no attempt at all to do a full-fledged cost-benefit analysis. Our research has highlighted the prospects of profitability of investing in tropical agriculture in the Netherlands Indies. This question invites three conclusions. First, compared to the average returns to equity investments in several other places of the world, the returns to investments in tropical agriculture in the Netherlands Indies were not exceptional, but they were certainly higher than investors could hope for when putting their money in the domestic economy. In that sense the benefits of empire are hard to deny. Second, it is also clear that part of these benefits were the indirect result of a colonial institutional framework that facilitated FDI in tropical agriculture since the Agrarian Law of 1870.

However, the profitability of colonial FDI also had a shadow-side, which investors may only be partly have realized when buying their stocks. Commodity markets were volatile, especially during the interwar rea, and the value of stocks in our BSE sample reflected this volatility. Large capital gains could be reaped in the mid-1920s, but profits could evaporate all of a sudden in the late 1920s and early 1930s. Given the higher risk profile of these stocks than investing in a composite index, part of the rates of return may thus have incorporated a risk-premium. What investors had probably not foreseen was the long-run instability of the colonial project. This risk unfolded not primarily in the 1930s, although investors had to cope with serious net losses, but especially in the 1940s and 1950s, when Dutch control over the archipelago crumbled, and Dutch assets were nationalized in the late 1950s. And although the Belgium companies in our sample were not hit by the nationalization campaign, they had long stopped making profits.

We are well aware that the small sample of companies that we could derive from the SCOB dataset limits firm conclusions regarding the profitability of FDI in the Netherlands Indies during the late colonial era. We have proposed a new avenue towards the comparative study of the profitability of empire. Should Amsterdam stock exchange data be digitized in the future, the opportunity will arise to reconsider the estimates presented here. But what we hope to have demonstrated here is that there is still ample scope for settling a long debate in Dutch historiography with new empirical material and methods of analysis.

Open Access This article is distributed under the terms of the Creative Commons Attribution 4.0 International License (http://creativecommons.org/licenses/by/4.0/), which permits unrestricted use, distribution, and reproduction in any medium, provided you give appropriate credit to the original author(s) and the source, provide a link to the Creative Commons license, and indicate if changes were made.

\section{Appendix}

See Table 5 . 


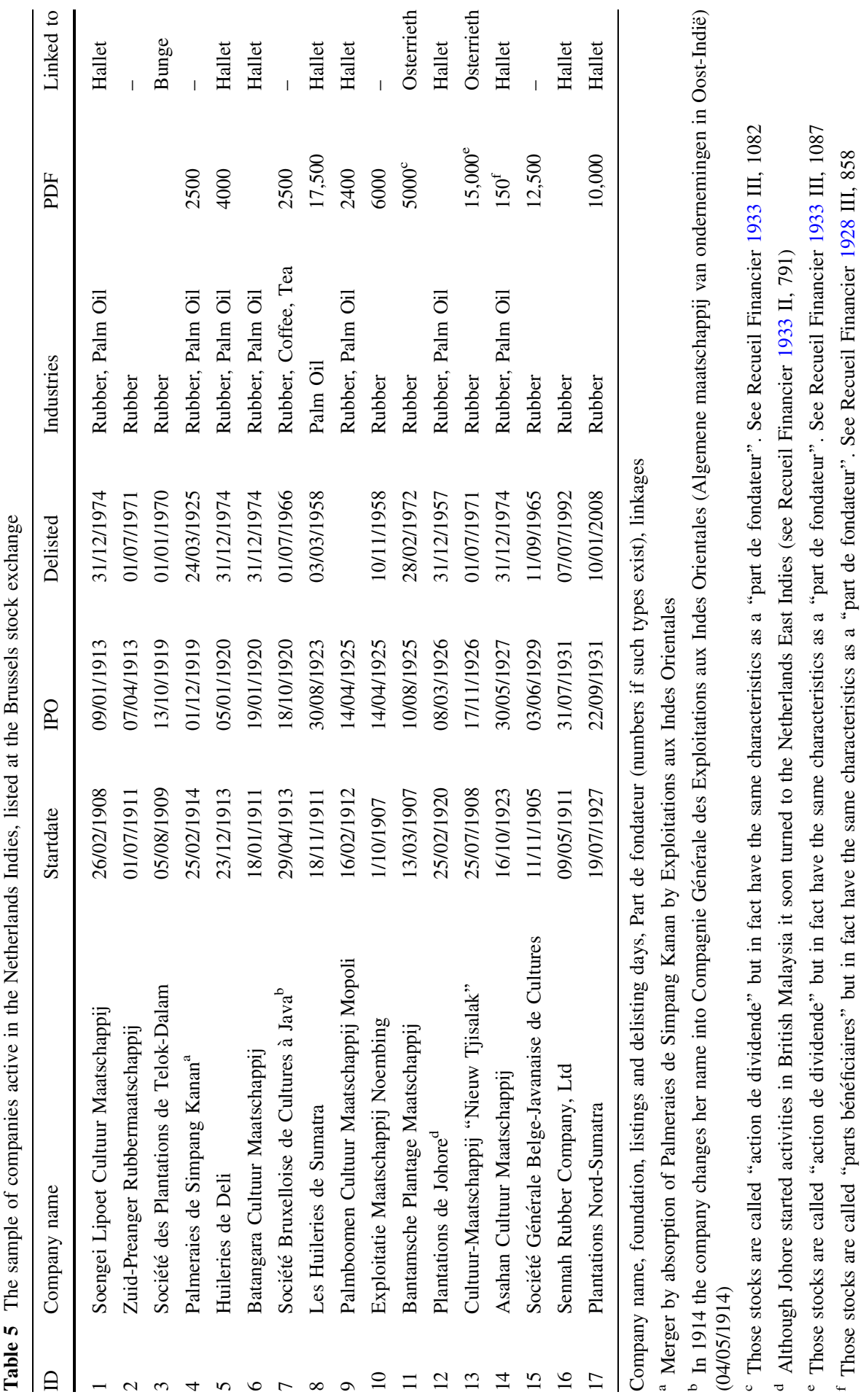




\section{References}

à Campo JNFM (1996) The rise of Corporate Enterprise in Colonial Indonesia 1893-1913. In Lindblad JT (ed), Historical foundations of a national economy in Indonesia, 1890s-1990s, North Holland, Amsterdam, pp 71-94

Allen GC, AG Donnithorne (1962 [1954]), Western Enterprise in Indonesia and Malaya. A study in Economic Development, 2nd ed. (1962). Allen and Unwin, London

Andaya BW, Andaya LY (1982) A history of Malaysia. Palgrave, Basingstone

Bambang Purwanto (1996) Monetary Policy in Colonial Indonesia and the Position of the Java Bank. In: Lindblad JT (ed) Historical Foundations of a National Economy in Indonesia, 1890s-1990s. North Holland, Amsterdam, pp 55-70

Baudet H (1980 [1975]) Nederland en de rang van Denemarken. Bijdragen en Mededelingen betreffende de Geschiedenis der Nederlanden 90:430-43 [REPRINTED IN Fasseur C (1980) Geld en geweten: een bundel opstellen over anderhalve eeuw Nederlands bestuur in de Indonesische archipel, Den Haag: Martinus Nijhoff, 241-256]

Baudet H, Fennema M (eds) (1983) Het Nederlands belang bij Indië. Analyse van de politieke en economische gevolgen van de dekolonisatie van Indonesië. Spectrum, Utrecht

Baudet MJ, Wijers GJ (1976) De Economische Betekenis van Nederlands-Indië voor Nederland Oude en Nieuwe Berekeningen. Economisch-Statistische Berichten 61:885-888

Baudhuin F (1944) Histoire Economique de la Belgique 1914-1939, vol II. Bruylant, Brussels

Baums T, Wymeersch E (1999) Shareholder voting rights and practices in Europe and the United States. Kluwer Law International, London/Cambridge/The Hague

Belgium. Ministry of Economics, CPI-index (Brussels) http://statbel.fgov.be/nl/statistieken/cijfers/ economie/consumptieprijzen/

Boeke JH (1940a) Indische Economie I. De theorie der Indische Economie. H.D. Tjeenk Willink en zoon, Haarlem

Boeke JH (1940b) Indische Economie II. H.D. Tjeenk Willink en zoon, De nieuwe Economische overheidspolitiek in Nederlandsch-Indië, Haarlem

Booth A (1996) Growth and stagnation in an Era of Nation-Building: Indonesian Economic Performance from 1950 to 1965. In: Lindblad JT (ed) Historical Foundations of a National Economy in Indonesia, 1890s-1990s. North Holland, Amsterdam, pp 401-423

Booth A (1998) The Indonesian economy in the nineteenth and twentieth centuries. A history of missed opportunities. MacMillan Press, London

Booth A (2007) Colonial Legacies: Economic and Social Development in East and Southeast Asia. University of Hawaï, Honolulu

Bosch KD (1948) Nederlandse beleggingen in de Verenigde Staten. Elsevier, Amsterdam

Boucheret M (2010) Famille Rivaud. In: Daumas JC (ed) Dictionnaire historique des Patrons Français. Flammarion, Paris, pp 602-605

Brandes J (1962) Herbert Hoover and Economic Diplomacy: Department of Commerce Policy. University of Pittsburgh Press, Pittsburgh

Breman J (1983) Control of Land and Labour in Colonial Java. A case study of Agrarian Crisis and Reform in the Region of Ceribon during the first Decades of the 20th Century. Floris, Dordrecht

Brion R, Moreau JL (2006) Van Mijnbouw tot Mars. De ontstaansgeschiedenis van Umicore. Tielt, Lannoo

Brocquet C, Cobbaut R, Gillet R, van den Berg A (1997) Gestion de Portefeuille. De Boeck, Brussels

Buelens F, Marysse S (2009) Returns on investments during the Colonial Era: the case of the Belgian Congo. Econ History Rev 65(S1):135-166

Callis H (1942) Foreign Capital in Southeast Asia. International Secretariat, Institute of Pacific Relations, New York

Caporin M, Jannin GM, Lisi F, Maillet B (2013) A survey on the four families of performance measures. J Econ Surv 28:1-26

Clarence-Smith WG (2013) Rubber cultivation in Indonesia and the Congo from the 1910s to the 1950s. Divergent paths. In: Frankema E, Buelens F (eds) Colonial exploitation and Economic Development The Belgian Congo and the Netherlands Indies Compared. Routledge, London, pp 193-210

Costa LF, Palma N, Reis J (2015) The great escape? The contribution of the empire to Portugal's economic growth, 1500-1800. Eur Rev Econ History 19(1):1-22 
Crena de Iongh D (1938) Nederlandsch-Indië als beleggingsgebied voor Nederlandsch kapitaal'. In: Gerretson C (ed) De sociaal-economische invloed van Nederlandsch-Indië op Nederland. H. Veenman en Zonen, Wageningen, pp 94-113

Davis LE, Huttenback RA (1986) Mammon and the Pursuit of Empire: the political economy of British Imperialism, 1860-1912. Cambridge University Press, Cambridge

De Jong L (1984) Het Koninkrijk der Nederlanden in de Tweede Wereldoorlog. Deel 11a. Nederlands Indië. 's Staatsuitgeverij, Gravenhage

De Haas JA (1938) The new economic policy of the Dutch East Indies. Harvard Bus Rev Spring 16(3):323-335

Derksen JBD, Tinbergen J (1945) Berekeningen over de Economische beteekenis van Nederlandsch-Indië voor Nederland. Maandschrift CBS (Centraal Bureau voor de Statistiek), 40, 10/12: 210-23 [REPRINTED IN Fasseur C. (1980), Geld en geweten: een bundel opstellen over anderhalve eeuw Nederlands bestuur in de Indonesische archipel, Den Haag: Martinus Nijhoff, pp 225-240]

Dick HW (1989) Japan's Economic Expansion in the Netherlands Indies between the first and the second World Wars. J Southeast Asian Stud 20(2):244-272

Dimson E, Marsh P, Staunton M (2002) Triumph of the Optimists: 101 years of Global Investment Returns. Princeton University Press, Princeton

Dimson E, Marsh P, Staunton M (2013) Crédit Suisse Global Investment Returns Sourcebook 2013. Crédit Suisse Research Institute, Zurich

Dormois J-P, Crouzet F (1998) The significance of the French Colonial Empire for French Economic Development, 1815-1960. J Iber Latin Am Econ History 16(01):22-23

Elson RE (1994) Village Java under the Cultivation System, 1830-1870. Allen \& Unwin, Sydney

Etambala ZA (2008) De teloorgang van een modelkolonie. Belgisch Congo 1958-1960. Acco, Leuven

Fieldhouse DK (1961) Imperialism: an historiographical revision. Econ History Rev 14:187-209

Forbin V (1943) Le caoutchouc dans le monde. Payot, Paris

Frankema E, Buelens F (eds) (2013) Colonial exploitation and economic Development. Routledge, London

Gann LH, Duignan P (1967) Burden of empire An appraisal of Western Colonialism in Africa South of the Sahara. F.A. Praeger, New York

Geertz C (1963) Agricultural involution: the process of ecological change in Indonesia. University of California Press, Berkeley

Gerretson C (1938) Historische inleiding. In: Gerretson C (ed) Sociaal-economische invloed van Nederlandsch-Indië op Nederland. H. Veenman en Zonen, Wageningen

Glissenaar F (2003) Indië verloren, rampspoed geboren. Uitgeverij Verloren, Hilversum

Gonggrijp G (1931) Répartition des activités économiques entre les colonies et la métropole. In: Proceedings of the institut colonial internationale, XXI session, Paris

Gonggrijp G (1957) Schets ener economische geschiedenis van Indonesië, 4th edn. De Erven F. Bohn NV, Haarlem

Gordon A (1998) Industrial development in colonial Indonesia, 1921-1941. J Contemp Asia 28(1):3-26

Gordon A (2010) Netherlands East Indies: the Large Colonial Surplus of Indonesia 1878-1939. J Contemp Asia 40(3):425-443

Gorter W (1964) Enkele gedachten over de economische betekenis van het verlies van Indonesië. De Economist 108(10):641-658

Haccoû JF (1961 [1984]) Nederlands-Indië economisch, een beeld van groei en strijd. In: Baudet H, Brugmans IJ (eds) Balans van Beleid. Terugblik op de laatste halve eeuw van Nederlandsch-Indië. Van Gorcum, Assen, pp 239-266

Hexner E (1946) International Cartels. University of North Carolina Press, Chapel Hill

Houben V, Seibert J (2013) (Un)freedom: colonial labor relations in Belgian Congo and the Netherlands Indies compared. In: Frankema E, Buelens F (eds) Colonial Exploitation and Economic Development: The Belgian Congo and the Netherlands Indies compared. Routledge, London, pp 178-192

Huillery E (2014) The Black Man's Burden: the cost of Colonization of French West Africa. J Econ Hist 74:1-38

International Labour Organization (1930) Indes Neerlandaises. Inf Soc 34(6):237-239

Keesing FAG (1978) De conjuncturele ontwikkeling van Nederland en de evolutie van de economische overheidspolitiek 1918-1939. SUN, Nijmegen

Keyser \& Zonen, Bank (1937) Nederlands-Indische Fondsen. Gegevens en statistieken voor beleggers. Bankierskantoor A.H. Keyser \& Zonen, Amsterdam 
Kuitenbrouwer M (1991) The Netherlands and the rise of modern imperialism: colonies and foreign policy, 1870-1902. Berg, New York

Kurgan-van Hentenryk G, Jaumain S, Montens V (eds) (1996) Dictionnaire des patrons en Belgique. Les hommes, les entreprises, les réseaux. De Boeck Université, Brussels

Lains P (1998) An Account of the Portuguese African Empire, 18851975. J Iber Latin Am Econ History 16(1):235-263

Lefeuvre D (2006) Pour en finir avec la répentance colonial. Flammarion, Paris

Lindblad JT (1989) Economic aspects of the Dutch Expansion in Indonesia, 1870-1914. Mod Asian Stud 23(1):1-24

Lindblad JT (1991) Foreign investment in Late-Colonial and Post-Colonial Indonesia. Econ Soc Sci Neth III: $183-208$

Lindblad JT (1993) Ondernemen in Nederlands-Indië, c.1900-1940. Bijdragen en Mededelingen betreffende de Geschiedenis der Nederlanden 108:699-710

Lindblad JT (1998) Foreign investment in Southeast Asia in the twentieth century. Macmillan, London

Lindblad JT (2013) Manufacturing and investment in Indonesia. In: Frankema E, Buelens F (eds) Colonial exploitation and economic Development. Routledge, London, pp 210-228

Maddison A (1989) Dutch income in and from Indonesia, 1700-1938. In: Maddison A, Prince GHA (eds) Economic growth in Indonesia. Foris Publications, Dordrecht, pp 1820-1940

Maddison A (1990) The Colonial Burden: a comparative perspective. In: Lal Deepak, Scott M (eds) Public policy and economic development; essays in honour of Ian Little. Clarendon Press, Oxford, pp 361-376

Marseille J (1984) Empire colonial et capitalisme français. Histoire d'une divorce. Albin Michel, Paris

Nobel J, Fennema M (1996) Economische elites na de dekolonisatie van Nederlands-Indië. verlies van posities, desintegratie van netwerken, verschuiving van zwaartepunten. In: Fennema M, Schijf H (eds) Nederlandse elites in de twintigste eeuw: continuïteit en verandering. University Press, Amsterdam, pp 15-38

O'Brien P (1988) The costs and benefits of British imperialism 1846-1914. Past Present 120(1):163-200

Offer A (1993) The British Empire, 1870-1914: A waste of money? Econ History Rev (New Series) 46(2):215-238

Prince GHA (1996) The Economy of Indonesian Smallholder Rubber 1890s-1940. In: Lindblad JT (ed) Historical Foundations of a National Economy in Indonesia, 1890s-1990s. North Holland, Amsterdam, pp 175-192

Recueil Financier (1893-1975) Brussels, Bruylant (various issues)

Sandberg C (1914) Indië verloren, rampspoed geboren. D.A. Daamen, Den Haag

Sauerbeck, A. (annual publications 1886-1951), 'Wholesale prices 1845-1950', Journal of the Royal Statistical Society, 49-114, various issues

Sluyterman K (2004) Ambitious strategies: Dutch multinationals between 1950 and 2000, Paper for the workshop 'The internationalisation of Dutch business', Utrecht

Stengers J (1977) La genèse d'une pensée coloniale. Leopold II et le modèle Hollandais. Tijdschrift voor Geschiedenis vol 90, pp 46-71

Stengers J (1989) Congo. Mythes et réalités, 100 ans d'histoire. Duculot, Paris

Thee KW (2013) Colonial Extraction in the Indonesian Archipelago: a long historical view. In: Frankema E, Buelens F (eds) Colonial exploitation and economic development: the Belgian Congo and the Netherlands Indies compared. Routledge, London, pp 41-59

US Bureau of the Census (1975) Historical Statistics of the United States: Colonial Times to 1970. Department of Commerce, Washington D.C.

van der Eng P (1998a) Economic benefits from colonial assets: the case of the Netherlands and Indonesia 1870-1958, Research Memorandum GD-39

van der Eng P (1998b) Exploring Exploitation: the Netherlands and Colonial Indonesia 1870-1940. J Iber Latin Am Econ History 16(1):291-321

van der Eng P (2010) The sources of long-term economic growth in Indonesia, 1880-2008. Explor Econ History 47(3):294-309

van der Zwaag J (1991) Verloren Tropische Zaken: De Opkomst En Ondergang Van De Nederlandse Handel-en Cultuurmaatschappijen in Het Voormalige Nederlands-Indie. Feniks Pers, Groningen

van Zanden JL (2004) On the efficiency of markets for agricultural products: rice prices and capital markets in Java, 1823-1853. J Econ History 64:1028-1055

van Zanden JL, Van Riel A (2000) Staat, instituties en economische ontwikkeling. Balans, Amsterdam Vandenbosch A (1938) The Netherlands Colonial Balance Sheet. South Econ J 4(3):328-338 
Vanthemsche G (2007) La Belgique et le Congo. Nouvelle Histoire de Belgique. Editions Complexe, Brussels

Weijers GA (1941) De strijd om de natuurlijke rijkdommen. De groote cultures. In: van Helsdingen WH (ed) Daar werd iets groots verricht. Elsevier, Amsterdam, pp 286-321

Wesseling HL (1988) Indië verloren. Rampspoed geboren. Bert Bakker, Amsterdam

Willems H (2000) Het meervoudig stemrecht in de algemene aandeelhoudersvergadering in België. Belgisch tijdschrift voor nieuwste geschiedenis 3-4:430-492

Williamson JG (2008) Globalization and the Great Divergence: terms of trade booms, volatility and the poor periphery, 1782-1913. Eur Rev Econ History 12(3):355-391

Williamson JG (2012) Commodity prices over two centuries: trends, volatility, and impact. Ann Rev Resour Econ 4:185-206 